Journal of Engineering Sciences, Assiut University, Vol. 40, No. 3, pp.745 -764, May 2012

\title{
THE DECEMBER 2010 HOUSEHOLD ENERGY SURVEY IN JORDAN
}

\section{Mohammed Awwad Al-Dabbas}

Department of Mechanical Engineering, Faculty of Engineering, Mutah

University, Mutah, Al-Karak 61710 Jordan

Tel: +962-795580449: madabbas@mutah.edu.jo, madabbas@yahoo.com

(Received March 31, 2012 Accepted April 23, 2012)

The household sector accounts for $20.9 \%$ of primary energy use in Jordan. Increase in energy-based living standards and more efficient energy use are major opposing trends in Jordan that affect household energy consumption. Governmental policies to influence household energy consumption are often contradictory and have brought mixed results.

Ministry Of Energy has completed two cycles of surveys for household energy in the years 2001, 2004; on the other hand. The December 2010 update survey has been carried out in Mutah University and it is the latest update for those previous surveys, the result and conclusions of which are presented in this paper.

Wood, LPG, electric heater and Kerosene are used extensively in most of the households. While the percentage of the households using solar waterheaters was $11 \%$. The energy policy analysis reveals the need for government intervention to promote solar water-heaters as well as regarding the unsatisfied heating demand.

KEYWORDS: Jordan; Domestic energy sector; wood, LPG, electric heater, solar collector.

\section{INTRODUCTION}

Jordan is a small Arab nation with insufficient supplies of water, oil and gas, and other natural resources. Figure 1 shows the number of Population in Jordan during the last five year in Jordan. As shown the Population growth rate in 2010 is $2.159 \%$ while the GDP is 14,190 million JD (M $€ 14,190)$,GDP per Capita is $425 \mathrm{JD}(€ 2,425)$ and the GDP Growth is $7 \%$ annually.

Jordan used privatization proceeds to markedly reduction of its public debt-toGross Domestic Product (GDP) ratio. The government ended subsidy levels for oil and gas and other consumer and manufactured favorable in 2008 in an effort to control the budget [1]. The main problems facing Jordan are reducing dependence on foreign grants, reducing the expanding budget deficit, attracting investments, and creating jobs. Jordan is currently exploring nuclear power generation to forestall energy shortfalls [1].

Jordan is totally dependent on imported crude oil and some petroleum products (except for some oil shale and natural gas) to meet domestic energy demand required for its socioeconomic development. The energy consumption grew at an average of $14 \%$ per year and the energy bill averaged at $13 \%$ of gross national product (GNP) and consumed most of the foreign exchange earned by exports of all Jordanian 
commodities in the last 3 decades. Figure 2 shows the electrical energy Production in 2010 [2].

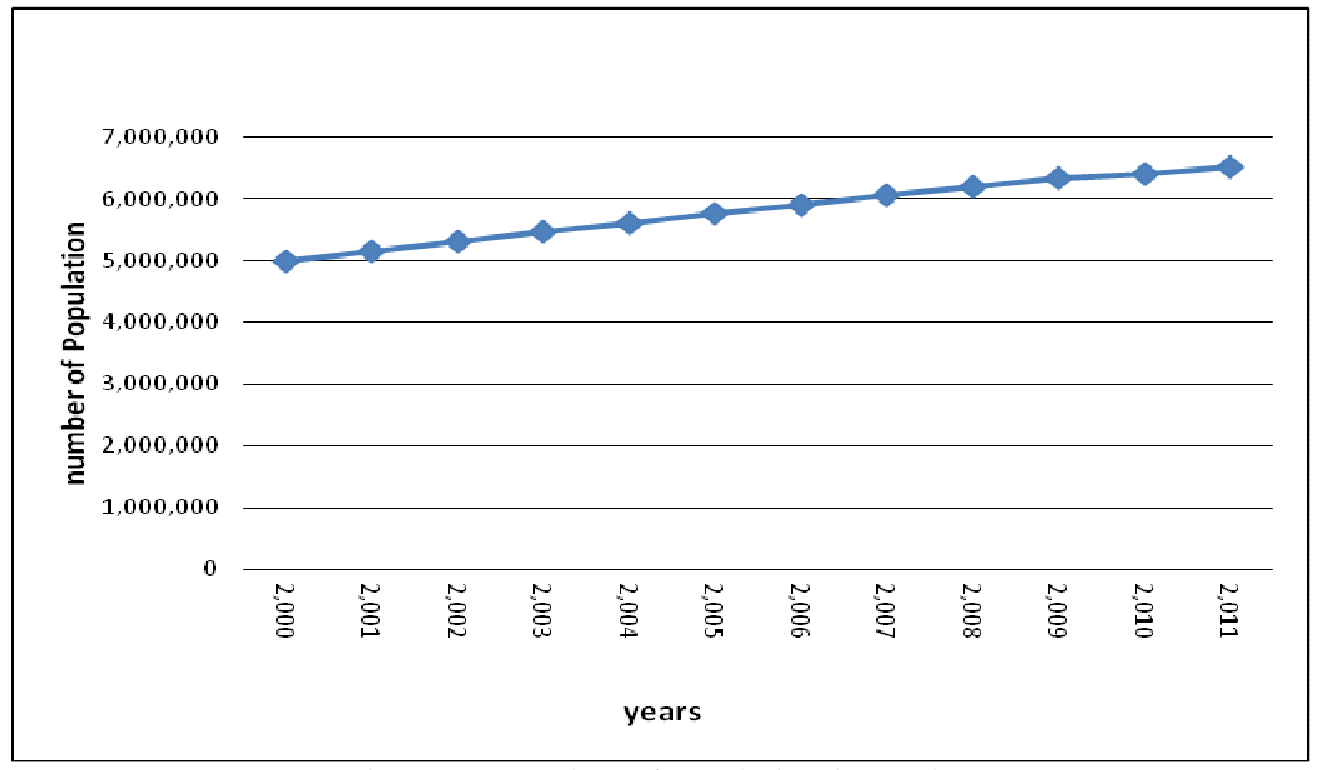

Figure 1: Number ofpopulation in Jordan

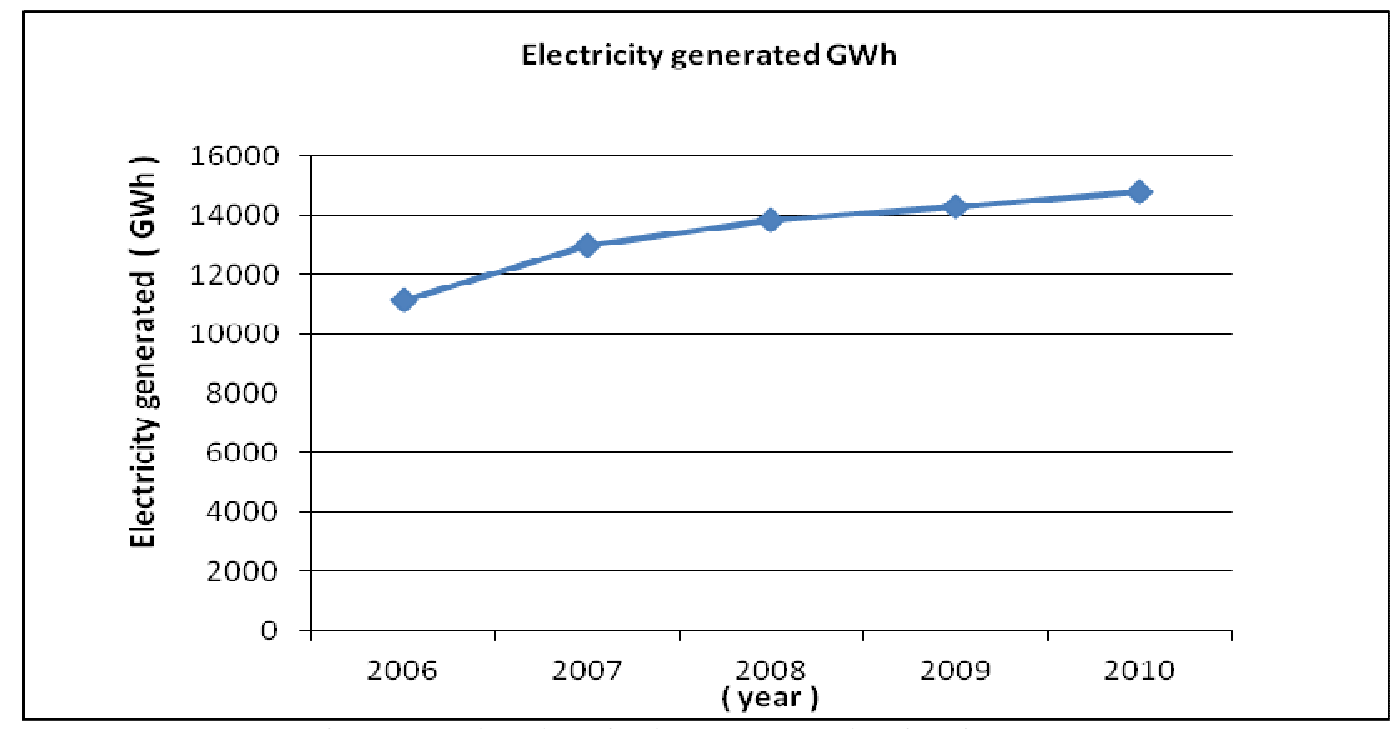

Figure 2: The electrical energy Production in 2010

In the field of the natural gas, $80 \%$ of the Kingdom's electricity energy in 2010 was generated out of the natural gas imported from Egypt, as the overall capacity of the electricity Power plants operating on the natural gas in the kingdom is $1880 \mathrm{MW}$ [3].

Figure 3 clarify the local production of crude oil and natural gas and its participation in the whole consumed energy in the Kingdome during the period 20052010 


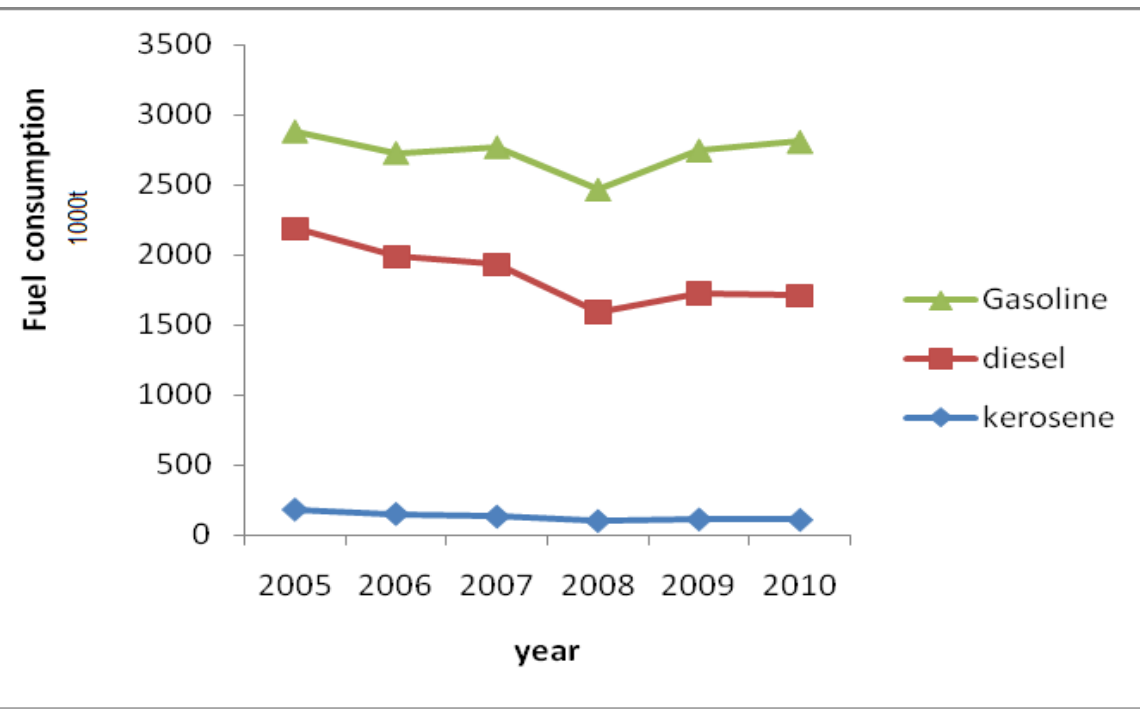

Figure 3: Jordan's production of crude oil and natural gas in (2005-2010)

The cost of the imported crude oil was around 1916 million JD in 2009, registering a decline of $30 \%$ from 2008 , and that's because of dropping the amounts of the imported crude oil in 2009 with nearly $4 \%$. In 2009, the overall demand for the primary energy was nearly 7739 million toe showing a growth rate of $5.5 \%$ beyond that 2008. Figure 4 demonstrates the renewable energy consumption in the Kingdom during the period 2005-2010 [4].

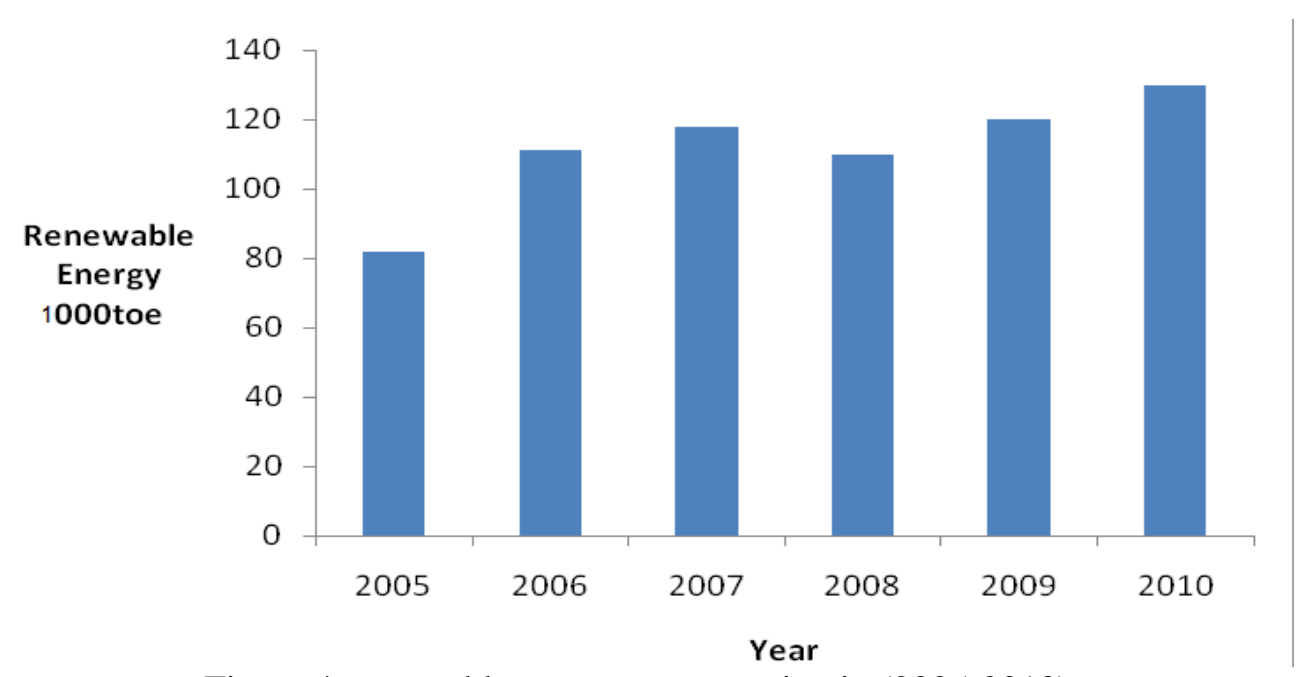

Figure 4: renewable energy consumption in (2005-2010)

Figure 5 shows the Percentage ratios of the sectoral distribution of final energy consumption in 2010. 


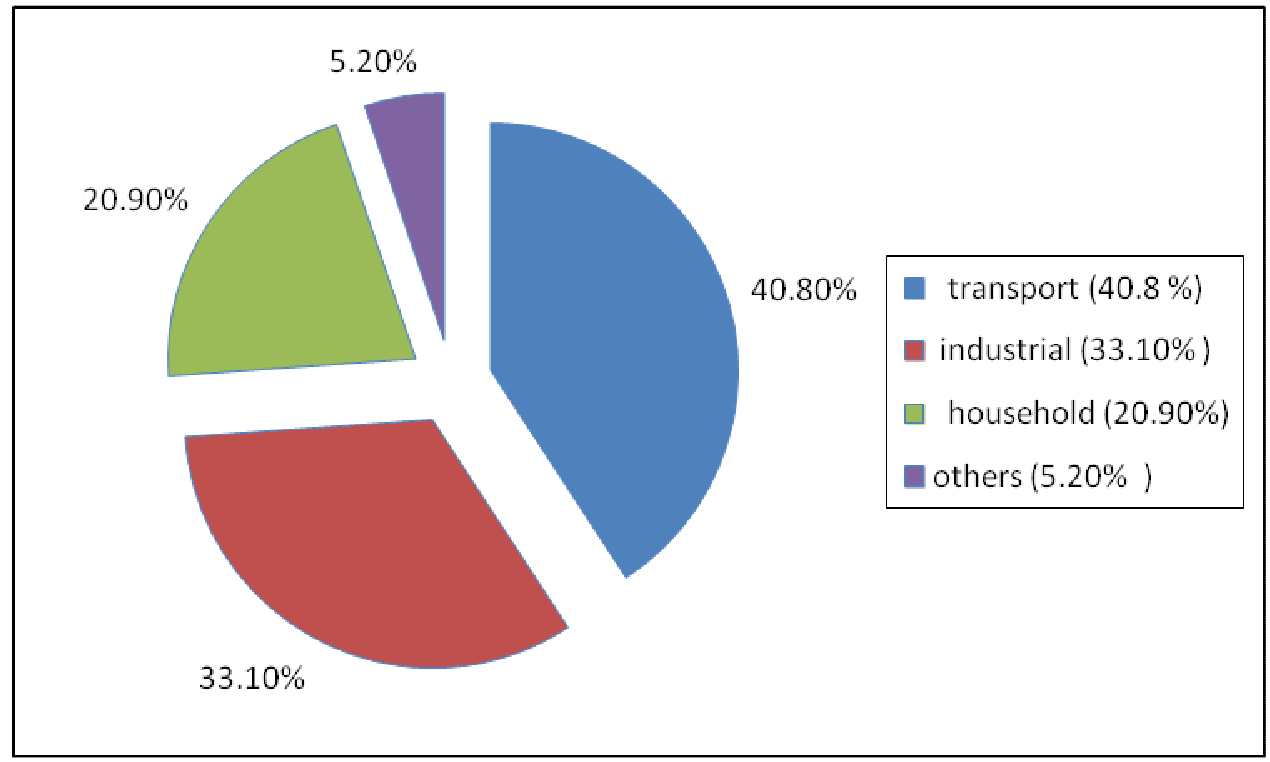

Figure 5: The sectoral distribution of final energy consumption. the year 2010.

While figure 6 shows the percentage of sectoral consumption of electricity in

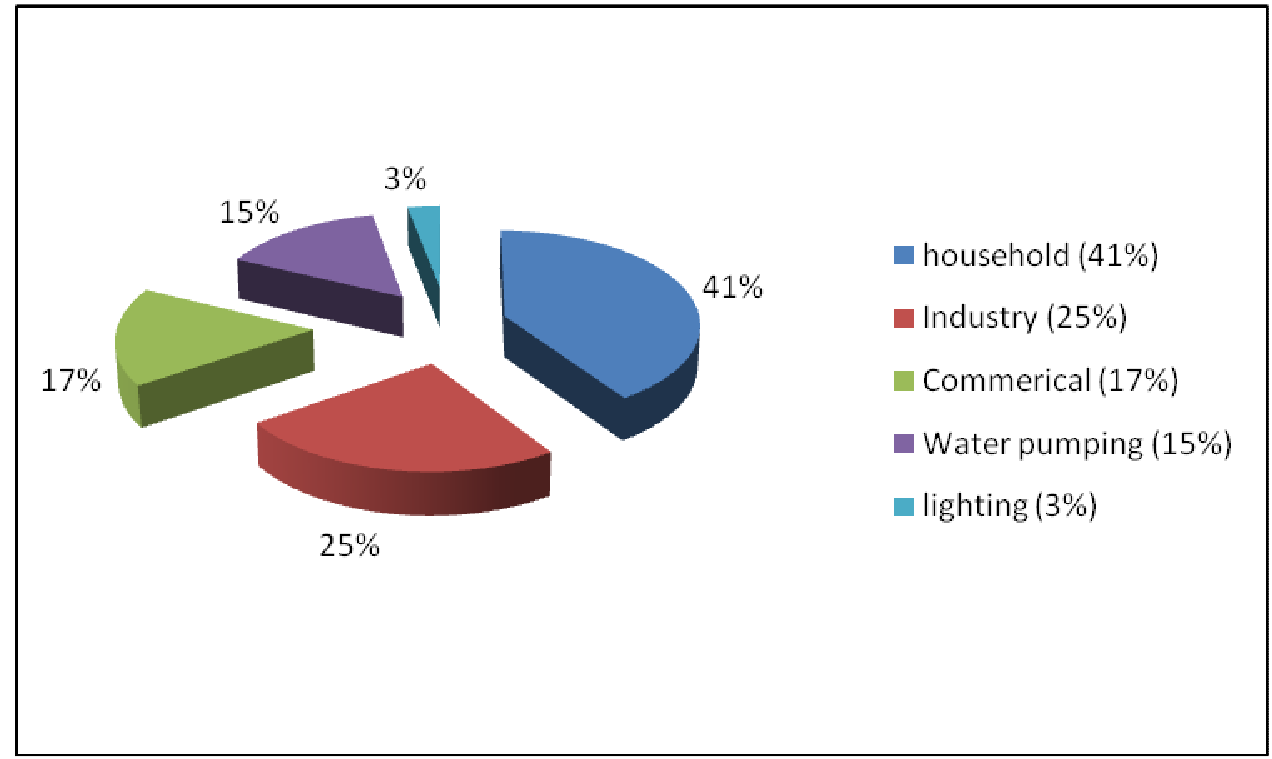

Figure 6: The rates of sectoral consumption of electricity in the year 2010

Jordan imports most of its energy needs. The energy issue has posed a difficult challenge for Jordan. Its lack of conventional commercial energy resources places a burden on the national economy due to the relatively high cost of imported oil and the high energy investment needed for economic and social development of the country.

Jordan is totally dependent on imported crude oil and some petroleum products (except for some oil shale and natural gas) to meet domestic energy demand required 
for its socioeconomic development. The energy consumption grew at an average of $14 \%$ per year and the energy bill averaged at $13 \%$ of gross national product (GNP) and consumed most of the foreign exchange earned by exports of all Jordanian commodities in the last 3 decades [2].

Figure 7 shows the distributed energy consumption in the household sector

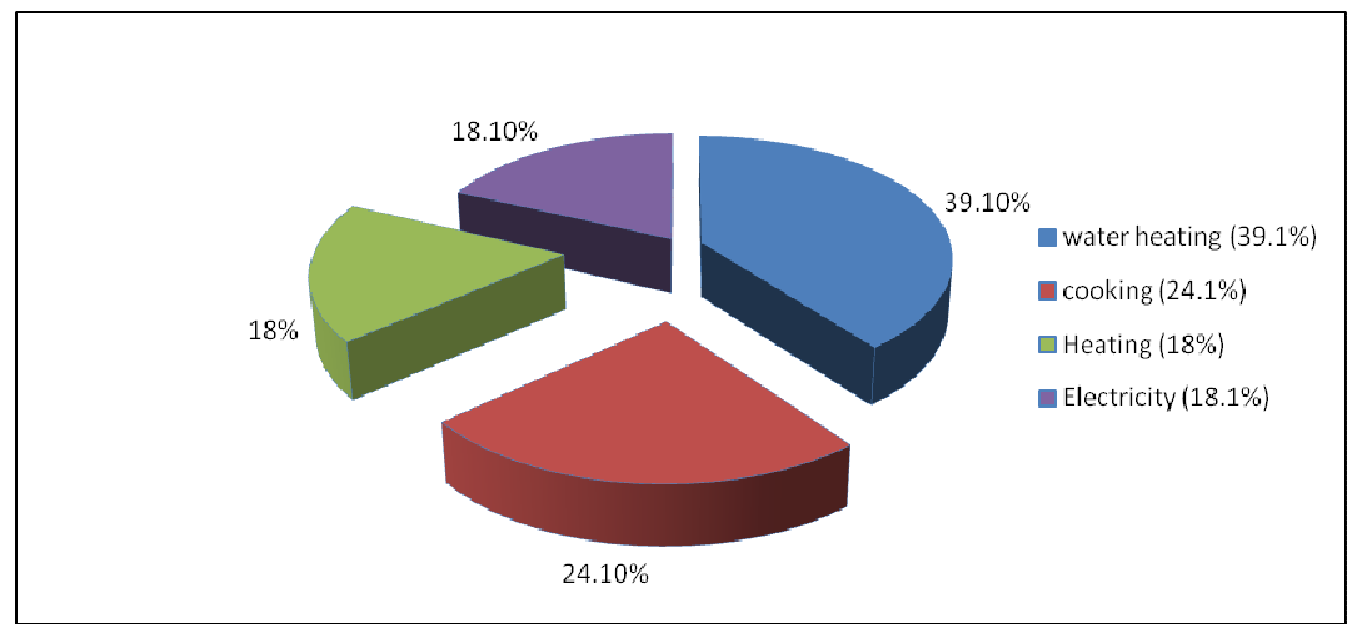

Figure 7: Energy consumption in the household sector

\section{ENERGY CONSUMPTION PROFILE}

Electricity production in Jordan is still predominantly based on thermal power plants, primarily using fuel and gas oil [5]. The tendency to move towards natural gas utilization is increasing due to the economic and environmental benefits of natural gas especially that gas networks are becoming increasingly available in Jordan. The installed capacities for the year 2010 in Jordan was 1657 MW [6].

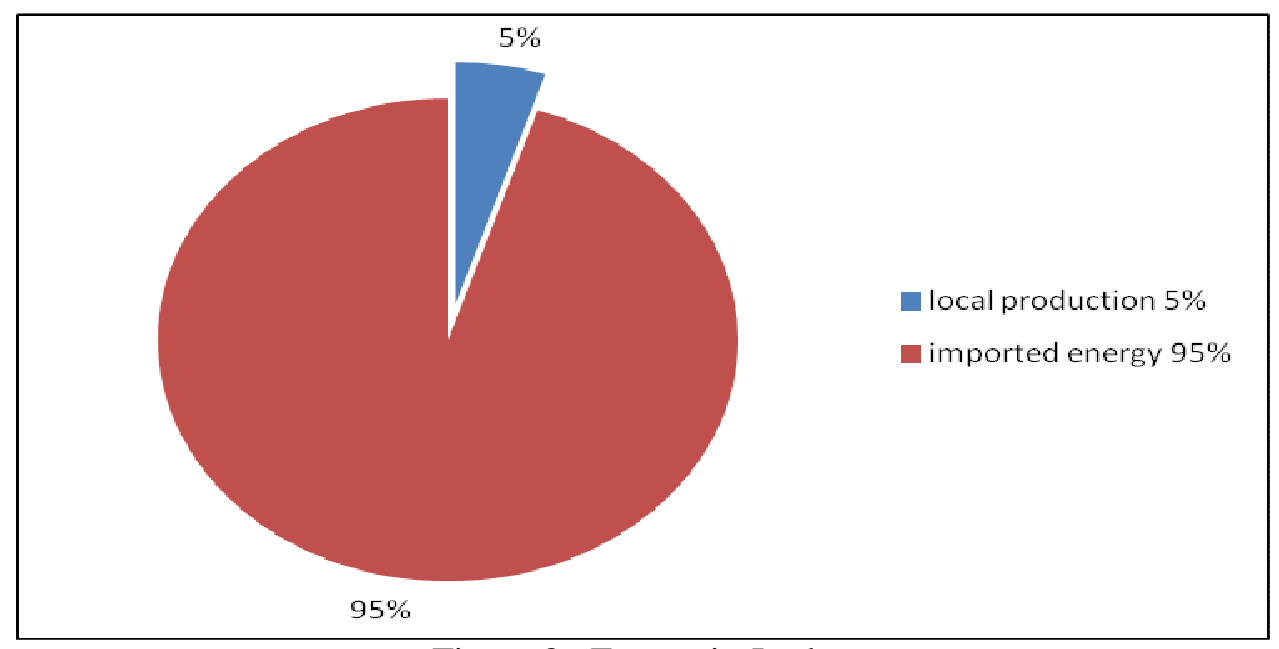

Figure 8 : Energy in Jordan 
Figure 9 shows the Electrical Energy Consumption used in Jordan. As shown $41 \%$ of energy consumption used by household sector

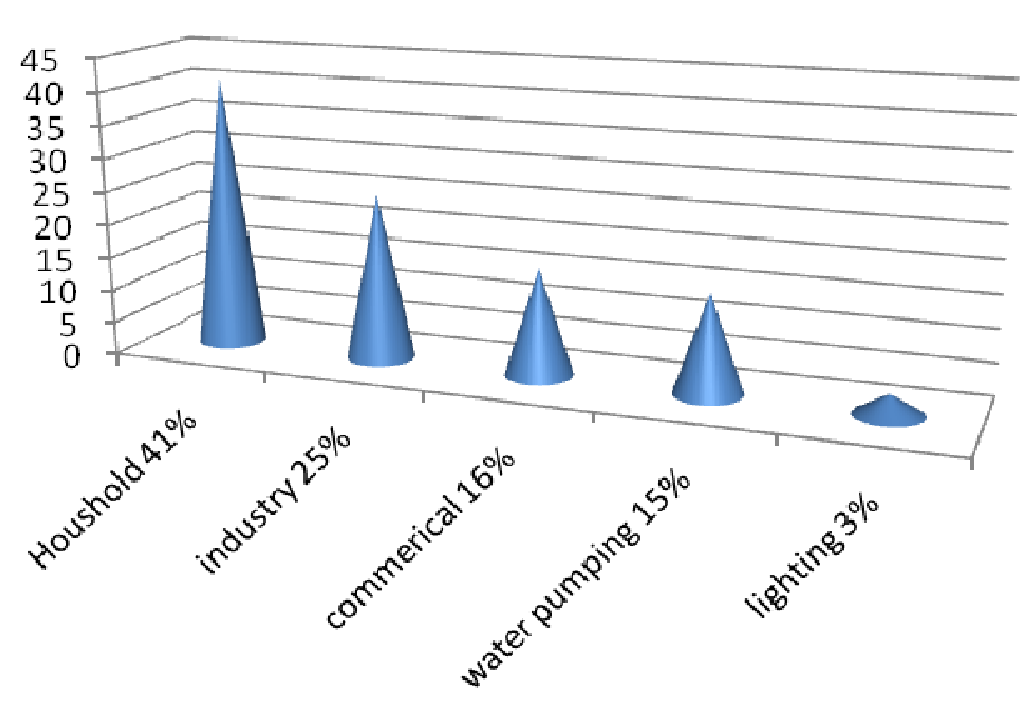

Figure 9: The Electrical Energy Consumption

\subsection{Solar energy}

- Photovoltaic application in Jordan

Figure 10 shows the PV application in Jordan in megawatt-peak (kWp)

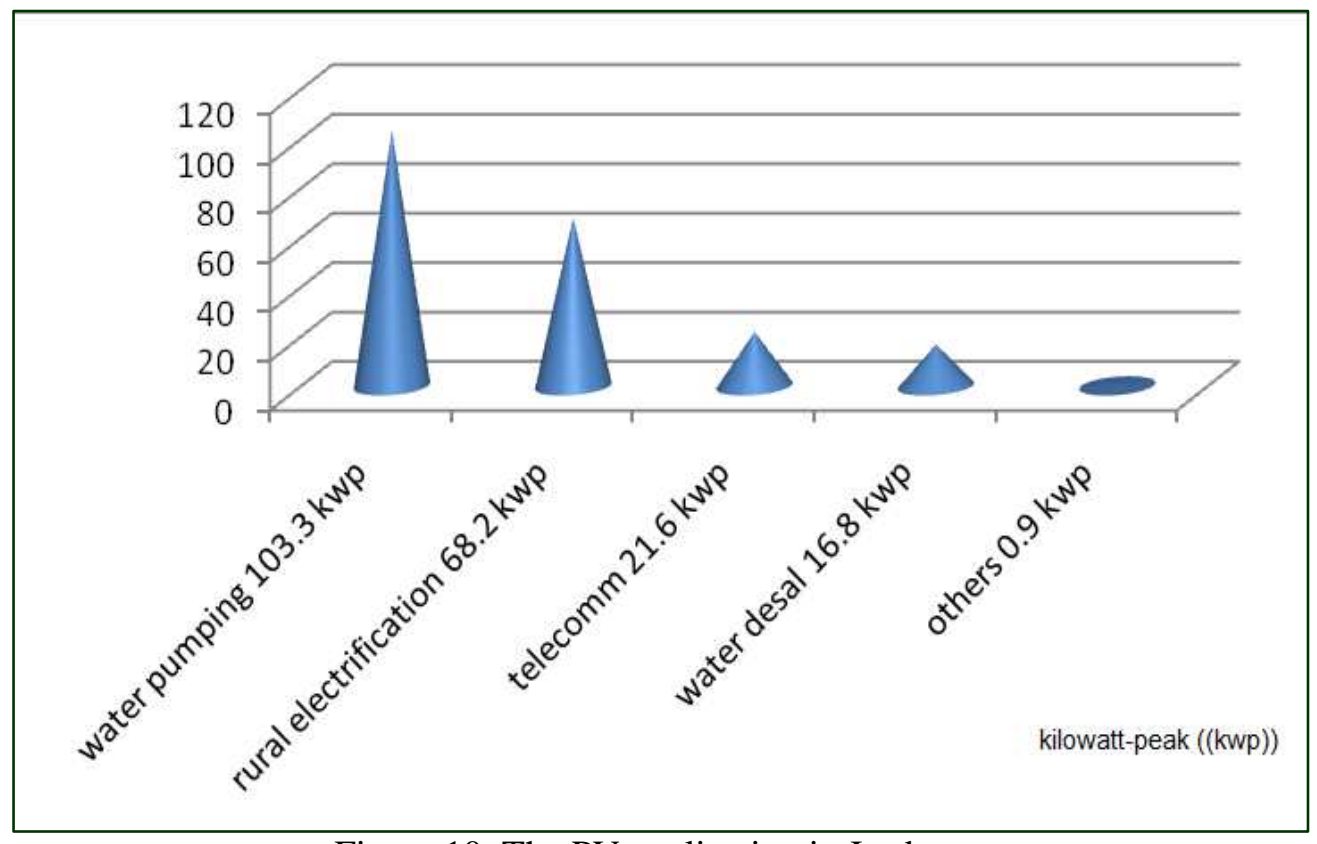

Figure 10 :The PV application in Jordan 


\section{- PV Current Projects in Jordan: Grid connected system}

1. $280 \mathrm{kWp}$ low voltage system is now under construction.

2. $1 \mathrm{MWp}$ system will installed at Muwaqar located at south of Jordan

\section{- Shams Ma'an Power Generation}

Shams Ma'an Power Generation PSC plans to construct the world's largest photovoltaic power plant in Ma'an, in the South of Jordan of $100 \mathrm{MW}$, which has secured a $2 \mathrm{sq}$ kilometer tract of land to build a photovoltaic (PV) solar energy plant, which will cost around $\$ 400$ million that can be expanded to 200 megawatts.

Figure 11 shows that the dependence on imported energy will be reduced by $35 \%$ at the end of 2020 as a result of expanding of renewable energy projects(solar, wind, biofuels..) and utilize domestic resources(oil shale, natural gas..)

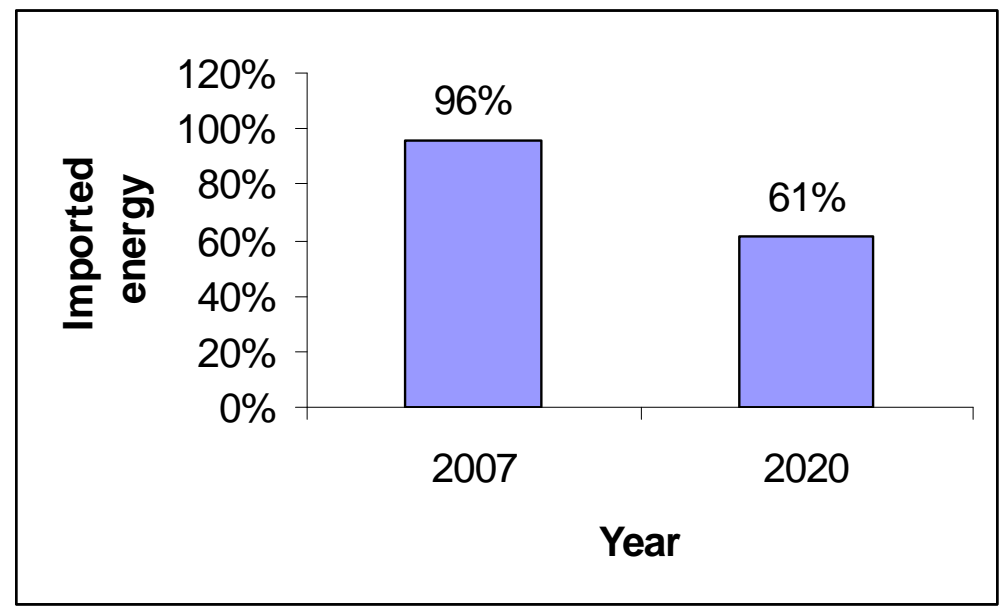

Figure 11: the dependence on imported energy

\subsection{Wind Energy [2]}

Jordan has rich wind energy resources. Studies on the wind potential have been made for several years and the available wind resources were assessed and based on which a Wind Atlas has been prepared, which shows that there is a potential of several hundreds of Megawatts of wind power installations in the country.

There are two operating wind farms in Jordan, one with a capacity of $320 \mathrm{~kW}$ $(4 \mathrm{X} 80 \mathrm{~kW})$, established in 1988 in cooperation with a Danish firm and considered as a pilot project. The other most recent one has a capacity of $1.12 \mathrm{MW}(5 \mathrm{X} 225 \mathrm{~kW})$, established in 1996 in cooperation with the German Government under a program called ELDORADO. Both wind farms are fully operated and maintained by CEGCO.

(Another info source indicated there were 4 stations; one in Hofa and another in AlIbrahimia, provide $22000 \mathrm{~kW}$ and the other two are still pilot projects, probably year 2000 - may have been expanded and upgraded later).

Depending on the promising results of those projects, the Ministry of Energy and Mineral Resources (MEMR) has issued the call for proposals for the development of a 75-90 MW wind IPP project, where two proposals are received and under evaluation. 
Wind Energy is also used for water pumping in Jordan, using a locally manufactured mechanical windmill. A long-term wind data collection (wind speed and direction) and evaluation is being implemented in Jordan. Twelve wind measuring systems were installed in promising sites.

\subsection{Renewable energy Law:}

The law was approved in febuary 2010, its aims are:

- Allowing companies for implementing RE project with the participating of the privet sector

- Electric tariff projects, incentives

- Establishment of RE\& EE fundfor supporting renewable energy project

- Connection to the grid for renewable energy projects.

\section{HOUSEHOLD ENERGY SURVEY (DECEMBER 2010)}

Most countries pay special attention for providing statistics on energy due to the important role of energy in reflecting the situation of the infrastructure, economic situation and the level of living standards of a society. In Jordan, additional special attention is given due to the shortage of natural resources, the high cost of energy and the high population density. All these factors create a need for comprehensive and high quality statistics on this field of study.

In spite of the attention for providing statistical data on household activities which were found to be the highest energy consuming sector, we decided to cover this sector by conducting a special household energy survey that provides high quality data about consumption of energy types, different energy consuming facilities used at household, and the behavior of this important sector.

This is the third study from the serial statistical studies in Jordan in 2010. And we hope that the results of this study will contribute to provide necessary data needed for developing energy situation in households and raising the consumption efficiency . Finally, we hope that this study will contribute to bridge the data gap of energy statistics and to provide useful data for the main data users and decision makers.

\subsection{The important of the study}

Energy has great importance due to its role in reflecting the country's economy, the people's welfare and their living standards. Also, energy data reflects the infrastructure situation [7].

We was established in Jordan to develop a national plan for energy statistics and to provide data about energy in Jordan in order taking into consideration the international recommendations of the United Nations in the field of energy and the special situation of the Jordan [7].

Because of the importance of the household sector and due to its large contribution to energy consumption in Jordan. Special household energy survey was demonstrated in Mutah University in December 2010 to provide data on energy consumption in the household sector and to provide data on energy consumption behavior in the society by type of energy [8]. 
This study presents data on various energy households' indicators in Jordan, and presents statistical data on electricity and other fuel consumption for the household sector, using type of fuel by different activities (cooking, baking, conditioning, lighting, and water heating).

Ministry Of Energy has completed two cycles of surveys for household energy in the year 2001, 2004 [9], on the other hand, we can consider the December 2010 update survey is the latest update for those previous surveys [7-14].

\subsection{Household energy prices [9]}

One of the important determinants of household energy demand and fuel mix is the price of various fuels. It is often difficult to estimate the effect of price in developing countries where a major part of energy consumption is met by traditional fuels that are gathered informally with no cash outlays. Noncash costs consist mostly of time (e.g., for gathering fuel wood) and hence are opportunity costs.

Commercial energy prices are often used as a social policy instrument in developing countries. Among the most common subsidized energy sources for households is electricity, with the aim of making it accessible even to low income households. However, in many cases such programmes result in effectively subsidizing higher income people who live in urban areas and have access to electricity grids. For the rural and urban poor, connection to the electricity supply is often prohibitively expensive or unavailable, even though the price of electricity itself may be low enough to encourage a switch from other fuels. In general, policies that keep energy prices low lead to growth in latent or potential household energy demand.

\subsection{The objectives of the study:}

In general, the objectives of the study include the following:

1. To obtain realistic estimates of the energy consumption of various kinds in the domestic sector.

2. Identify consumption patterns prevailing in the domestic sector.

3. Provide information on opportunities for using renewable energy (solar energy).

4. Provide data concerning the characteristics of buildings such as building design and construction and the type of heated and air-conditioned spaces.

5. Provide data about the devices used in the domestic sector and consumer of energy.

\subsection{Methodology}

The household energy survey questionnaire was designed in accordance with similar country experience indicators, taking into account the special situation of Jordan and with international standards and recommendations for the most important. The household energy survey questionnaires were distributed among large group of students from Mutah University. Those students representing the various governorates of Jordan.

It should be noted also that the participants in the mobilization of this form are students at the university stage, which gave the most accurate scientific results and better than previous studies 


\section{RESULTS AND DISCUSSIONS}

This paper presents the findings of the household energy survey that conduct in Mutah University in December 2010. These results were divided into four parts. The first part introduces the results related to energy sources in the domestic sector during December 2010, while the second part introduces the results related to the facilities used in conditioning and cooking. The third part presents the use purposes of energy types in the different activities in the households. The fourth presents the household and per capita consumption of the different energy types.

Jordan's energy is a very difficult challenge because of the lack of local sources of commercial energy and its dependence on import at the time that it needs to relatively large amounts of energy needed for economic and social growth.

In light of this fact and in light of the economic and social development being implemented which aims to improve the quality of life for Jordanian citizens, the demand for energy in Jordan will grow at a high rate of up to about $3 \%$ per year in general and about $6 \%$ in the consumption of electric power in particular.

This situation, in addition to high oil prices in recent frenzy arranged on the state budget high financial burden that exceeded JD 1916 million and accounted for about $32 \%$ of the gross domestic product in 2009 forced the ministry of energy

These circumstances have forced the Ministry of Energy to take practical procedure to minimize the impact of this bill on the national economy, and these measures include the following

- The application of an effective national strategy and clear vision in the energy sector aimed at providing the necessary energy for the overall development of the lowest possible cost and reduce the burden on the national economy.

- expression of the rationalization of energy consumption and raise efficiency in all economic and social sectors of the most important elements of this strategy

- more efficient use of energy by reducing waste and reducing waste and improving the techniques without affecting the levels of living and production, Consequently tens of millions of hard currency annually on the state budget will be saved as well as reduce the emission of polluting gases to the environment.

From here it was not necessary that there be accurate statistical data relating to all aspects of the above in order to implement this strategy correctly. The best way to provide such data is the surveys and statistical studies of all economic sectors in the community. And studying the patterns of energy consumption in the domestic sector was set aside to meet the special needs of these energy statistics.

The demographics characteristic of the Household Energy Survey are presented in tables (1to6)

Table (1): The percentage of the houses according to their kind

\begin{tabular}{|l|c|c|c|c|}
\hline Type of house & $\begin{array}{c}\text { Middle } \\
\text { Region }\end{array}$ & $\begin{array}{c}\text { North } \\
\text { Region }\end{array}$ & $\begin{array}{c}\text { South } \\
\text { Region }\end{array}$ & Total \\
\hline 1 & 39.19 & 63.40 & 71.96 & 58.18 \\
\hline 2 & 56.50 & 34.61 & 26.74 & 39.28 \\
\hline 3 & 4.31 & 1.99 & 1.30 & 2.54 \\
\hline Total & 100 & 100 & 100 & 100 \\
\hline
\end{tabular}


Table (2): The percentage of the houses according to year of building

\begin{tabular}{|l|c|c|c|c|}
\hline Type of house & $\begin{array}{c}\text { Middle } \\
\text { Region }\end{array}$ & $\begin{array}{c}\text { North } \\
\text { Region }\end{array}$ & $\begin{array}{c}\text { South } \\
\text { Region }\end{array}$ & Total \\
\hline $2000-2004$ & 14.55 & 8.96 & 7.77 & 10.43 \\
\hline $1995-1999$ & 13.21 & 13.42 & 13.41 & 13.35 \\
\hline $1990-1994$ & 13.65 & 18.33 & 17.23 & 16.40 \\
\hline $1985-1989$ & 14.20 & 16.21 & 15.09 & 15.17 \\
\hline $1980-1984$ & 16.18 & 12.21 & 13.11 & 13.83 \\
\hline $1975-1979$ & 8.23 & 10.53 & 11.43 & 10.06 \\
\hline $1970-1974$ & 6.75 & 10.38 & 11.59 & 9.57 \\
\hline $1965-1969$ & 4.03 & 4.02 & 3.97 & 4.01 \\
\hline $1960-1964$ & 2.74 & 2.01 & 2.44 & 2.40 \\
\hline Before 1960 & 2.38 & 1.97 & 1.98 & 2.11 \\
\hline Not knowing & 4.08 & 1.96 & 1.98 & 2.67 \\
\hline Total & 100 & 100 & 100 & 100 \\
\hline
\end{tabular}

Table (3): The percentage of the houses according to area of building

\begin{tabular}{|l|c|c|c|c|}
\hline Type of house & $\begin{array}{c}\text { Middle } \\
\text { Region }\end{array}$ & $\begin{array}{c}\text { North } \\
\text { Region }\end{array}$ & $\begin{array}{c}\text { South } \\
\text { Region }\end{array}$ & Total \\
\hline Not knowing & 6.19 & 4.03 & 2.89 & 4.37 \\
\hline $1-50$ & 3.32 & 9.97 & 12.69 & 8.66 \\
\hline $51-100$ & 38.26 & 41.39 & 50.69 & 43.45 \\
\hline $101-150$ & 34.13 & 28.69 & 22.30 & 28.37 \\
\hline $151-200$ & 13.01 & 12.04 & 9.15 & 11.40 \\
\hline $201-250$ & 3.01 & 2.01 & 1.52 & 2.18 \\
\hline Above 250 & 2.08 & 1.87 & 0.76 & 1.57 \\
\hline Total & 100 & 100 & 100 & 100 \\
\hline
\end{tabular}

Table (4): The percentage of the houses according to number of rooms

\begin{tabular}{|l|c|c|c|c|}
\hline Type of house & $\begin{array}{c}\text { Middle } \\
\text { Region }\end{array}$ & $\begin{array}{c}\text { North } \\
\text { Region }\end{array}$ & $\begin{array}{c}\text { South } \\
\text { Region }\end{array}$ & Total \\
\hline Not knowing & 0.07 & - & - & 0.02 \\
\hline 1 & 7.32 & 8.37 & 11.41 & 9.03 \\
\hline 2 & 32.84 & 36.21 & 39.85 & 36.30 \\
\hline 3 & 42.03 & 38.62 & 33.74 & 38.13 \\
\hline 4 & 13.75 & 13.82 & 11.91 & 13.16 \\
\hline 5 & 2.87 & 1.83 & 1.84 & 2.18 \\
\hline 6 & 0.74 & 0.82 & 0.93 & 0.83 \\
\hline $7 \&$ above & 0.38 & 0.33 & 0.32 & 0.34 \\
\hline Total & 100 & 100 & 100 & 100 \\
\hline
\end{tabular}


Table (5): The percentage of the houses according to possession of house

\begin{tabular}{|l|c|c|c|c|}
\hline Type of house & $\begin{array}{c}\text { Middle } \\
\text { Region }\end{array}$ & $\begin{array}{c}\text { North } \\
\text { Region }\end{array}$ & $\begin{array}{c}\text { South } \\
\text { Region }\end{array}$ & Total \\
\hline 1 & 83.38 & 74.51 & 83.38 & 76.58 \\
\hline 2 & 16.01 & 23.53 & 16.01 & 21.85 \\
\hline 3 & .61 & 1.96 & .61 & 1.57 \\
\hline Total & 100 & 100 & 100 & 100 \\
\hline
\end{tabular}

Table (6): The percentage of the houses according to Monthly rent

\begin{tabular}{|l|c|c|c|c|}
\hline Type of house & $\begin{array}{c}\text { Middle } \\
\text { Region }\end{array}$ & $\begin{array}{c}\text { North } \\
\text { Region }\end{array}$ & $\begin{array}{c}\text { South } \\
\text { Region }\end{array}$ & Total \\
\hline Not knowing & 1.03 & 1.46 & 3.90 & 2.13 \\
\hline $1-50$ & 11.34 & 48.54 & 61.15 & 40.34 \\
\hline $51-100$ & 35.92 & 38.35 & 30.01 & 34.76 \\
\hline $101-150$ & 46.69 & 7.65 & 3.90 & 19.41 \\
\hline 150 and above & 5.02 & 4.01 & 1.04 & 3.36 \\
\hline Total & 100 & 100 & 100 & 100 \\
\hline
\end{tabular}

\section{The most important results and statistical indicators}

\section{A- Results pertaining to consumption:}

1. Consumption of the domestic sector were $21 \%$ (2004, Ministry of energy), and $23 \%$ (2010, current survey) of the total energy consumption of the Kingdom, respectively.

2. Consumption of the domestic sector of diesel constitutes $13 \%$ (2004, Ministry of energy), 14\%(2010, current survey) of the total consumption of the Kingdom of diesel and 22\%(2004, Ministry of energy), 24\%(2010, current survey) of the total consumption of the domestic sector of the different types of energy respectively.

3. Consumption of the domestic sector of kerosene constitutes 95\%(2004, Ministry of energy), $96 \%$ (2010, current survey) of the total consumption of the Kingdom of kerosene and 22\%(2004, Ministry of energy), 24\%(2010, current survey) of the total sector consumption of different types of energy respectively.

4. Consumption of the domestic sector of liquefied natural gas represents more than $92 \%$ (2004, Ministry of energy), 94\%(2010, current survey)of the total consumption of the Kingdom of liquefied gas. and which represent 31\%(2004, Ministry of energy), 33\%(2010, current survey) of the total consumption of the domestic sector of the different types of energy respectively.

5. Consumption of the domestic sector of the electric power about 35\% (2004, Ministry of energy), 45\%(2010, current survey) of the total consumption of the Kingdom of electricity and 24\%(2004, Ministry of energy), 30\%(2010, current survey) of the total consumption of the domestic sector of the different types of energy respectively. 
The rates of use of different types of energy

Tables 7-18 show the most result from household survey

Table 7: Average household consumption of kerosene according to type of use

\begin{tabular}{|l|l|l|}
\hline & $\mathbf{2 0 0 4}$ & $\mathbf{2 0 1 0}$ \\
\hline Water heating & 2.13 & 2.2 \\
\hline Cooking & 0.91 & 0.91 \\
\hline lighting & 0.65 & 0.62 \\
\hline Heating system & 76.79 & 74 \\
\hline
\end{tabular}

Table 8: Average household consumption of LPG according to type of use

\begin{tabular}{|l|l|l|}
\hline & $\mathbf{2 0 0 4}$ & $\mathbf{2 0 1 0}$ \\
\hline Heating system & 64.82 & 70 \\
\hline Cooking & 100 & 100 \\
\hline Water heating & 20.3 & 25 \\
\hline
\end{tabular}

Table 9: Number of flat plate collectors

\begin{tabular}{|l|l|l|}
\hline & $\mathbf{2 0 0 4}$ & $\mathbf{2 0 1 0}$ \\
\hline $\mathbf{2}$ & 4.77 & 4 \\
\hline $\mathbf{3}$ & 53.18 & 50 \\
\hline $\mathbf{4}$ & 26.82 & 24 \\
\hline $\mathbf{5}$ & 0.23 & 0.15 \\
\hline
\end{tabular}

Table 10: Most problem of solar collectors

\begin{tabular}{|l|l|l|}
\hline & $\mathbf{2 0 0 4}$ & $\mathbf{2 0 1 0}$ \\
\hline Freezing & 12.05 & 12 \\
\hline Fracture & 22.72 & 22 \\
\hline corrosion & 7.05 & 7 \\
\hline
\end{tabular}

Table 11: Type of insulation material

\begin{tabular}{|l|l|l|}
\hline & $\mathbf{2 0 0 4}$ & $\mathbf{2 0 1 0}$ \\
\hline Polystyrene & 52.61 & 50 \\
\hline Rock wall & 15.22 & 17 \\
\hline air & 29.13 & 40 \\
\hline
\end{tabular}

Table 12: Insulation of ceiling

\begin{tabular}{|l|l|l|}
\hline & $\mathbf{2 0 0 4}$ & $\mathbf{2 0 1 0}$ \\
\hline Asphalt & 10.28 & 8 \\
\hline Ground Floor Tiles & 33.2 & 31 \\
\hline Cement Slope Pour & 49.85 & 52 \\
\hline
\end{tabular}


Table 13 : Average Household Consumption of Electricity

\begin{tabular}{|l|l|l|}
\hline & $\mathbf{2 0 0 4}$ & $\mathbf{2 0 1 0}$ \\
\hline heating & 2.74 & 2 \\
\hline condition & 100 & 100 \\
\hline cooking & 9.88 & 8 \\
\hline Lighting & 100 & 100 \\
\hline Heating water & 23.12 & 20 \\
\hline washing & 98.43 & 98 \\
\hline
\end{tabular}

Table 14: The percentage of the houses according to Heating Facility

\begin{tabular}{|l|c|c|c|c|}
\hline Type of house & $\begin{array}{c}\text { Middle } \\
\text { Region }\end{array}$ & $\begin{array}{c}\text { North } \\
\text { Region }\end{array}$ & $\begin{array}{c}\text { South } \\
\text { Region }\end{array}$ & Total \\
\hline Not knowing & - & - & - & - \\
\hline 1 & 9.63 & 9.69 & 9.62 & 9.65 \\
\hline 2 & 20.34 & 20.40 & 21.01 & 20.58 \\
\hline 3 &. &. &. &. \\
\hline 4 & .21 & .27 & .25 & .24 \\
\hline 5 & 1.24 & 1.30 & 1.28 & 1.27 \\
\hline 11 & 50.96 & 51.02 & 49.83 & 50.60 \\
\hline 12 & 17.62 & 17.32 & 18.01 & 17.65 \\
\hline Total & 100 & 100 & 100 & 100 \\
\hline
\end{tabular}

Table 15: The percentage of the houses that used kerosene

\begin{tabular}{|l|c|c|c|c|}
\hline Type of house & $\begin{array}{c}\text { Middle } \\
\text { Region }\end{array}$ & $\begin{array}{c}\text { North } \\
\text { Region }\end{array}$ & $\begin{array}{c}\text { South } \\
\text { Region }\end{array}$ & Total \\
\hline Yes & 14.60 & 20.05 & 9.60 & 14.75 \\
\hline no & 85.40 & 79.95 & 90.40 & 85.25 \\
\hline Total & 100 & 100 & 100 & 100 \\
\hline
\end{tabular}

Table 16: The percentage of the houses according to type of heating system

\begin{tabular}{|l|c|c|c|c|}
\hline Type of house & $\begin{array}{c}\text { Middle } \\
\text { Region }\end{array}$ & $\begin{array}{c}\text { North } \\
\text { Region }\end{array}$ & $\begin{array}{c}\text { South } \\
\text { Region }\end{array}$ & Total \\
\hline Heating facility & 14.60 & 20.05 & 9.60 & 14.75 \\
\hline Diesel heaters & 3.6 & 13.96 & 6.92 & 8.16 \\
\hline Central heating & 10.25 & 5.47 & 2.47 & 6.06 \\
\hline others & 0.75 & 0.62 & 0.21 & .53 \\
\hline Heating water & 6.89 & 3.87 & 2.15 & 4.30 \\
\hline Heating boiler & 5.96 & 2.58 & 1.29 & 3.28 \\
\hline Diesel boiler & 0.93 & 1.29 & 0.86 & 1.03 \\
\hline
\end{tabular}




\section{Table 17: The percentage of the houses that used boiler heating system}

\begin{tabular}{|l|c|c|c|c|}
\hline Type of house & $\begin{array}{c}\text { Middle } \\
\text { Region }\end{array}$ & $\begin{array}{c}\text { North } \\
\text { Region }\end{array}$ & $\begin{array}{c}\text { South } \\
\text { Region }\end{array}$ & Total \\
\hline Yes & 10.25 & 5.47 & 2.47 & 6.06 \\
\hline no & 4.35 & 14.58 & 7.13 & 8.69 \\
\hline
\end{tabular}

Table 18: The percentage of the houses according to heating system

\begin{tabular}{|lc|c|c|c|c|}
\hline \multicolumn{2}{|c|}{ Type of house } & $\begin{array}{c}\text { Middle } \\
\text { Region }\end{array}$ & $\begin{array}{c}\text { North } \\
\text { Region }\end{array}$ & $\begin{array}{c}\text { South } \\
\text { Region }\end{array}$ & Total \\
\hline $\begin{array}{l}\text { Traditional } \\
\text { system }\end{array}$ & heating & 32.59 & 45.63 & 52.69 & 43.64 \\
\hline $\begin{array}{l}\text { Modern heating } \\
\text { system }\end{array}$ & 67.41 & 54.37 & 47.31 & 56.36 \\
\hline Total & 100 & 100 & 100 & 100 \\
\hline
\end{tabular}

\section{Diesel:}

Figure 12 show the fuel consumption (thousand tons) in last five years in the kingdom.

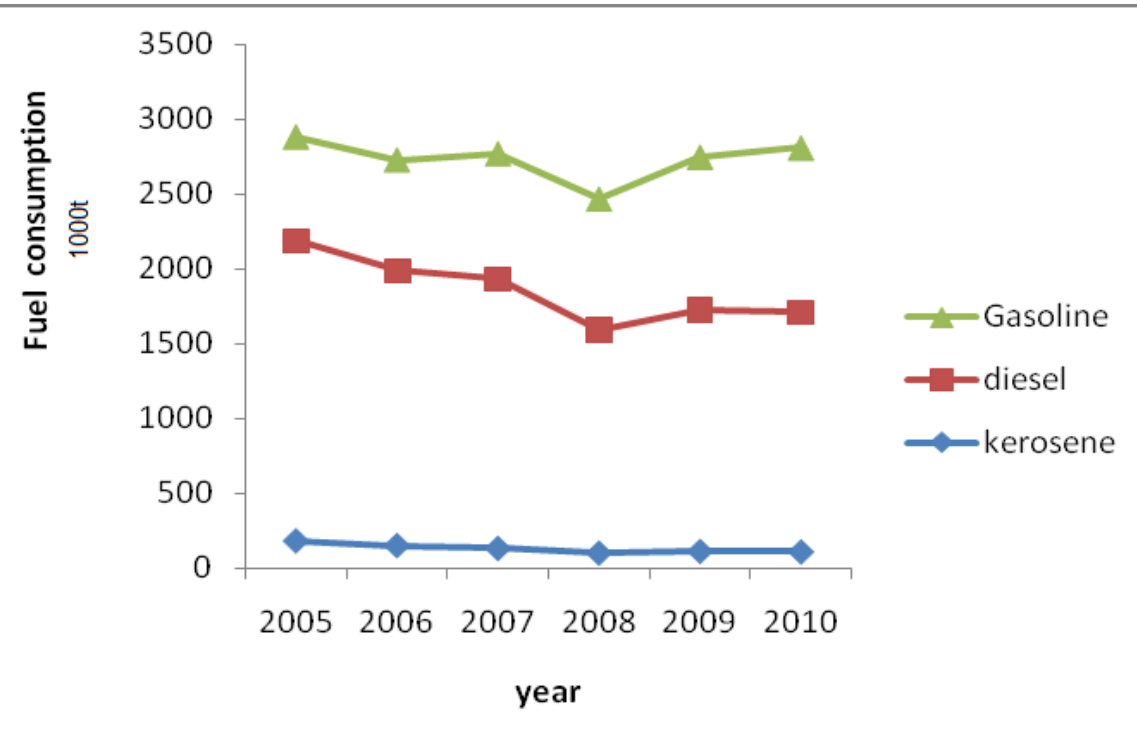

Figure 12: the fuel consumption (thousand tons) in last five years.

As shown in figure 12, the growth rates of fuel consumption of gasoline, diesel, and kerosene in last five years are $17 \%, 11 \%, 8 \%$, respectively. It should be mention that:

- The percentage of users of diesel in the domestic sector in the Kingdom about $14 \%$, in 2004(Ministry of energy), $15.54 \%$ in 2010(current survey), respectively. 
- The percentage of homes that use central heating in the Kingdom about $9 \%$ in 2004(Ministry of energy), $10 \%$ in 2010(current survey), respectively.

- The percentage of homes that use diesel for heating water in the Kingdom about 5\% in 2004(Ministry of energy), and 5.55\% in 2010(current survey), respectively.

\subsection{Kerosene:}

The percentage of homes that use kerosene for heating purposes in the domestic sector in the Kingdom about 77\% in 2004(Ministry of energy), and 75\% in 2010(current survey), respectively.

\subsection{LPG:}

The findings of the survey indicate that the average household liquefied petroleum gas consumption in Jordan during December 2010 was $25 \mathrm{~kg}$ per person, The percentage of users of LPG in the domestic sector in the Kingdom about 99.9\% in 2004(Ministry of energy), and $99.2 \%$ in 2010(current survey), respectively.

- The percentage of homes that use LPG for heating purposes in the Kingdom about $65 \%$ in 2004(Ministry of energy), and 60\% in 2010(current survey), respectively.

- The percentage of homes that use LPG for heating water in the Kingdom about $20 \%$ in 2004(Ministry of energy), and 40\% in 2010(current survey), respectively.

\subsection{Gasoline Consumption:}

Figure 13 shows the natural gas consumption in Kingdom during the last six years in MBtu

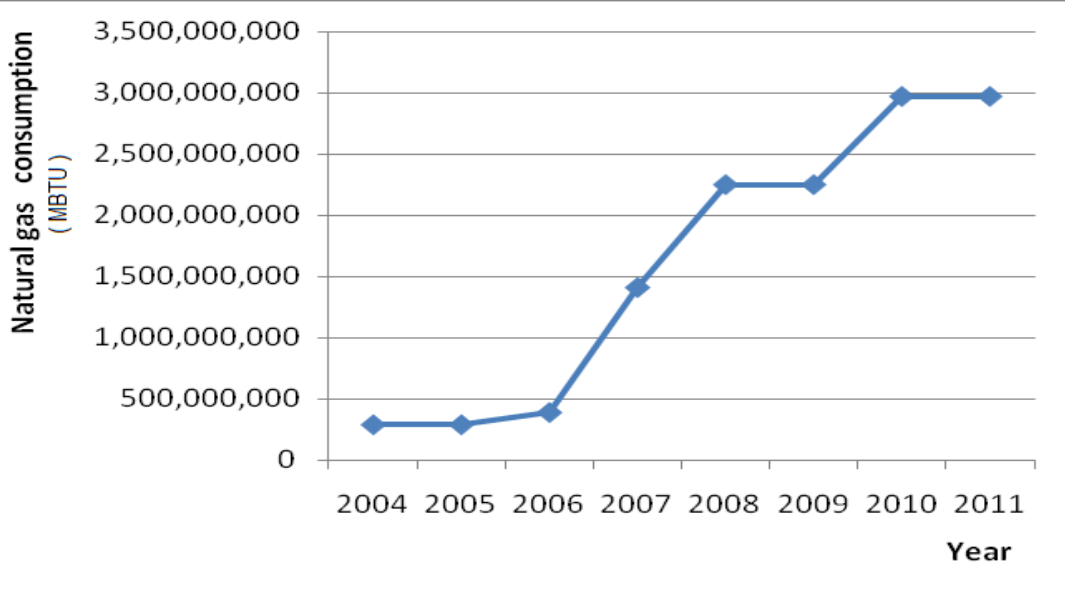

Figure 13: Natural gas consumption (MBtu)

\subsection{Electric power:}

- The percentage of users of electric power in the domestic sector in the Kingdom about $99.96 \%$ in 2004(Ministry of energy), and 99\% in 2010(current survey), respectively. 
- The percentage of homes that use electricity for heating water in the Kingdom about 23\% in 2004(Ministry of energy), and 45\% in 2010(current survey), respectively.

- The percentage of homes that use electric-conditioners for cooling purposes in the Kingdom about 4\% in 2004(Ministry of energy), and 75\% in 2010(current survey), respectively.

\subsection{Solar collectors:}

- The percentage of homes that use solar heaters is actually in the Kingdom about $16 \%$ in 2004(Ministry of energy), and 11\% in 2010(current survey), respectively.

- The percentage of homes that have solar heaters, whether working or not working about 19\% in 2004(Ministry of energy), and 15\% in 2010(current survey), respectively.

- The most important reasons that prevent the installation of solar heaters in the housing due to high price, where the percentage reached about $38 \%$ in the Kingdom in 2004(Ministry of energy), and 35\% in 2010(current survey), respectively.

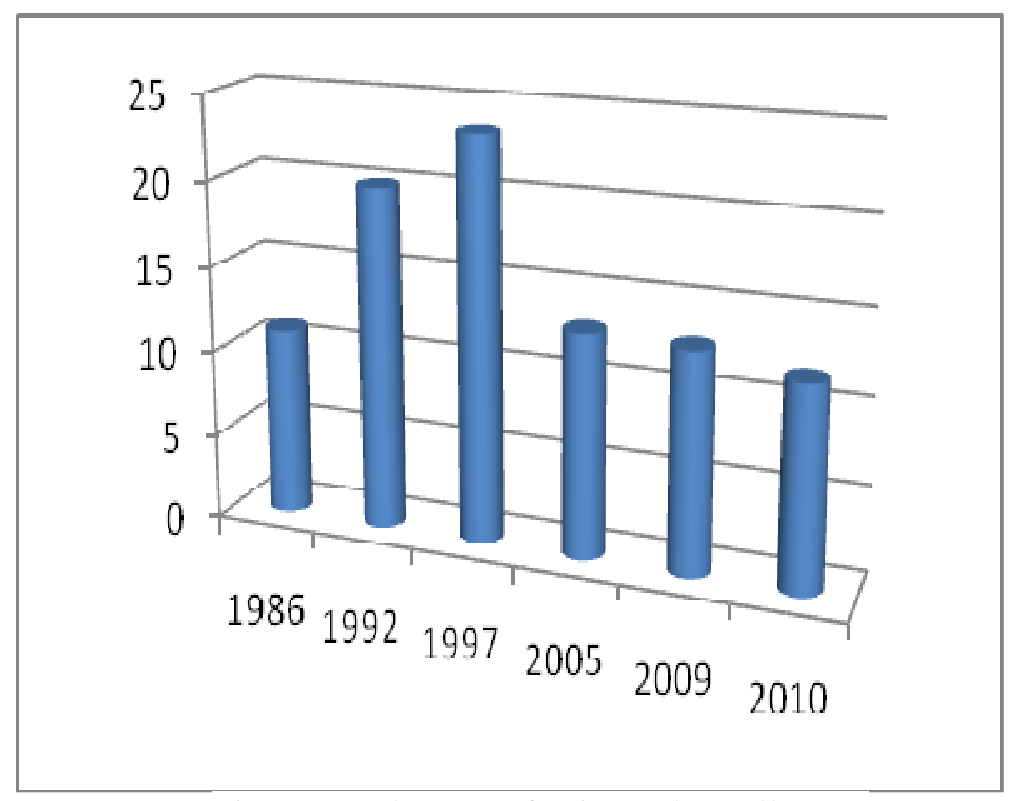

Figure 14: the rate of using solar collectors

\subsection{Wood Consumption:}

The data of the survey show that the average household wood consumption in Jordan during December 2010 was 25\% for heating purposes in 2010(current survey) in the east of Amman, south and north of the kingdom.

The rationalization of energy consumption Indicators that relate to the rationalization of energy consumption: 
- The percentage of dwellings that have knowledge of the means of rationalization about $90 \%$ in the Kingdom in 2004(Ministry of energy), and 94\% in 2010(current survey), respectively.

- The percentage of homes that use thermal insulators to isolate the walls of the house about 10\% in 2004(Ministry of energy), and 12\% in 2010(current survey), respectively.

- Polystyrene is much used in thermal insulation in urban areas where the percentage reached about 57\% in 2004(Ministry of energy), and 52\% in 2010(current survey), respectively.

- The percentage of insolated surface houses about $44 \%$ in the Kingdom in 2004(Ministry of energy), and 52\% in 2010(current survey), respectively.

- Cement Slope pouring is the most important means to isolate the roof of the house in the Kingdom where the rate was about 50\% in 2004(Ministry of energy), and $54 \%$ in 2010(current survey), respectively.

- The most important methods used in the rationalization of consumption of electric energy are extinguishing the lamps during the natural lighting, as well as turn off lights in empty rooms where the rate was in the Kingdom about $34 \%$ in 2004(Ministry of energy), and 65\% in 2010(current survey), respectively.

\subsection{Energy Sources:}

\section{Energy Consumption Facilities}

35\% of households in Jordan have used conditioning facilities in December 2010. Also, the results of the survey indicate that $40 \%$ of households in Jordan have used heating facilities.

\section{Energy Uses:}

The data show that $99 \%$ of households in Jordan depend on LPG as a main fuel for preparing food (cooking) in December 2010.

The findings of the survey indicate that $35 \%$ of households in Jordan condition their houses in December 2010, and 100\% of households depend on electricity as main fuel for household conditioning.

Also, the results showed that $35 \%$ of the households depend on electricity as main source for heating, $100 \%$ of households in Jordan depend on electricity as a main source for lighting in December 2010.

\section{CONCLUSIONS}

The results of the survey indicate that $99.9 \%$ of households in the Jordanian were connected to the public electricity network in 2010. From the results, the average household consumes $350 \mathrm{KWh}$ of electricity monthly.

Most (35\%) households depend on kerosene or gas heaters for warmth in the winter, while $35 \%$ depend on wood for warm in the winter. And only $40 \%$ have a central heating system 
Around $96 \%$ of the households own a TV while $90 \%$ own a satellite receiver, the data of the survey show that $11 \%$ of households in Jordan are utilizing solar energy by using solar energy heaters in December 2010.

1. Jordan has limited energy resources such as oil shale deposits, tar sands, a small hydropower potential, a few low geothermal sources and biogas. With exception of natural gas, solar and wind energy, Jordan's endowment of energy is modest.

2. Most of Jordan's known energy reserves, such as oil shale, heavy oil, tar sands, are not of high quality. In addition, their exploration, development and utilization are rather difficult and currently not economically feasible.

3. The share of renewable energy in the total primary energy consumption is around $2 \%$. The strategy calls for increasing the utilization of renewable energy as it is environmentally beneficial.

4. Natural gas is being used for power generation

\section{REFERENCES:}

1. http://www.economywatch.com/economic-statistics/country/Jordan/

2. http://webfea-lb.fea.aub.edu.lb/fea/research/erg/RCW/Status\%20of\%20Jordan\%25

3. Annul Report, 2011, Ministry of Energy and Mineral Resources, Amman, Jordan NERC (National Energy Research Center) web site.

4. http://www.indexmundi.com/jordan/population_growth_rate.html

5. Sami Karaki, Farid Chaaban, Riad Chedid, and Toufic Mezher," Electric Energy Access in Jordan, Lebanon and Syria", Draft Paper Prepared for "Energy Access II" Working Group Global Network on Energy for Sustainable Development http://webfealb.fea.aub.edu.lb/fea/research/erg/web/Energy\%20Access\%20Paper AUB.pdf

6. N. Ghaddar, T. Mezher, R. Chedid, M. Fadel, and F. Moukalled "Renewable Energy Technology" Working Group Global Network on Energy for sustainable Development 1250001-5 RETs Theme Final Report on Renewable Energies Technologies Contribution and Barriers to Poverty Alleviation in Jordan, Syria, and Lebanon http://gnesd.org/Downloadables/RETs/ERG\%20RETs\%20final\%20version.pdf

7. http://www.pcbs.org/cgi-sys/suspendedpage.cgi

8. Ministry of Energy and Mineral Resources, 2004, Household energy demand in Jordan in 2004".

9. R. Aburas, "Energy conservation policies in Jordan, Energy Policy, Volume 17, Issue 6, December 1989, Pages 591-598

10. Oleg Dzioubinski, Ralph Chipman, "Trends in Consumption and Production: Household Energy Consumption", April 1999, United Nations, ST/ESA/1999/DP. 6, DESA Discussion Paper No. 6

11. http://www.un.org/esa/sustdev/publications/esa99dp6.pdf

12. Annual Report on Environmental Statistics, 2010, Department of Statistics, Amman, Jordan

13. “Jordan Agenda 21” Towards Sustainable Development, UNDP, Jordan , 2000 


\section{مسع استهلاك الطاقة في الاردن كانون الاول 2010 \\ اعداد :الاكتور/ محمد عواد الاباس}

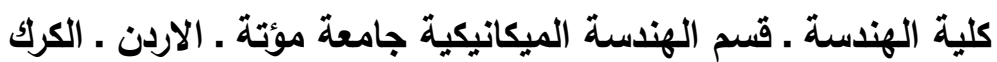

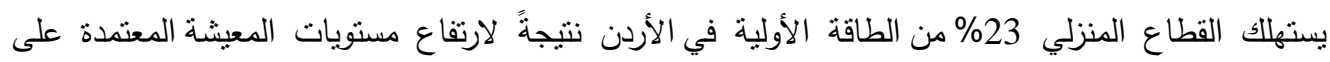

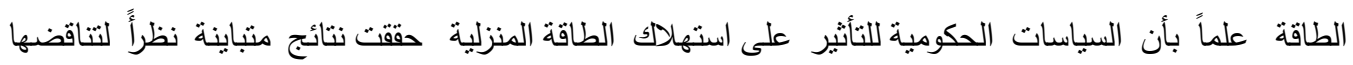
وعلى الرغم من زيادة كفاءة استخدام اجهزة الطاقة.

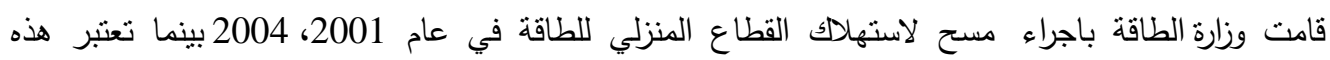

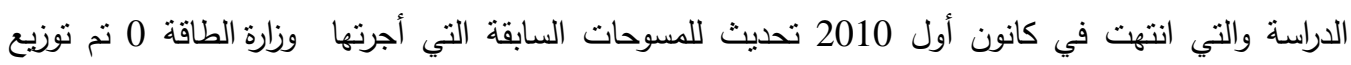

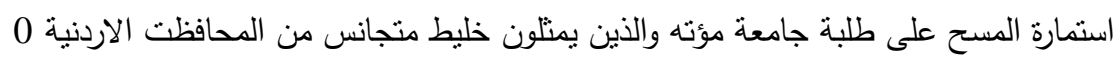

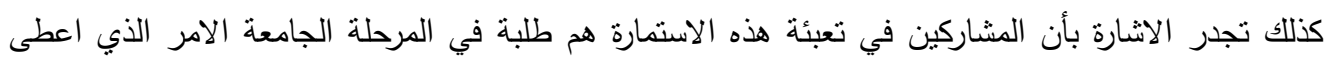
نتائج علمية ادق وأفضل من الدراسات السابقة 0 أظهرت الدراسة ان القطاع المنزلي يستهلك الخشب، وغاز البترول المسال،السخان الكهربائي ومادة الكيروسين

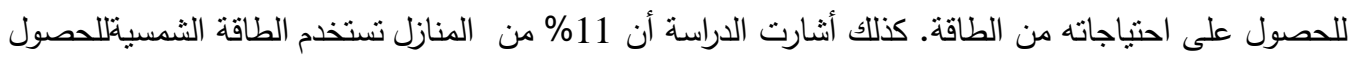
على المياه الساخنة الامر الذي ينطلب الحاجة لتخل الحكومة لتعزيزوتثجيع استخدام الطاقة الثمسية كأحد الحلول لنقليل الطلب على الطاقة . 